\title{
Political Connection Impairs Enterprise Innovation: An Empirical Study Based on Chinese Private Listed Enterprises
}

\author{
Haoxiang Tong ${ }^{1} \&$ Huili Xiao ${ }^{2}$ \\ ${ }^{1}$ Ph.D. (Finance), PBC School of Finance, Tsinghua University, Beijing, China \\ Correspondence: Haoxiang Tong, PBC School of Finance, Tsinghua University, Beijing, China. E-mail: \\ tonghx.16@pbcsf.tsinghua.edu.cn
}

Received: April 20, 2019

Accepted: May 7, 2019

Online Published: May 20, 2019

doi:10.5539/ijef.v11n7p1

URL: https://doi.org/10.5539/ijef.v11n7p1

\begin{abstract}
Based on various data of the private listed companies in China, this paper stuides the impact of political connections on corporate innovation capabilities. Political connection can improve corporate value, bring financing convenience, tax benefits as well as government subsidy to affiliated enterprises. On the other hand, political connection helps affiliated enterprises enter the monopoly industries, which weakens their willingness to engage in innovative activities. The empirical studies reveal that political connection has a negative innovation effect, due to it raises the entry level of entering barrier industry in affiliated enterprises.
\end{abstract}

Keywords: political connection, private listed corporation, incentive damage, innovation capabilities

\section{Introduction}

At present, the development of China's economy suffers from the outbreak of contradictions, which growth rate shifting, structural adjustment pains, and stimulus policy digestion are merged. China must deepen reform to resolve structural contradictions in the economy, further rationalize the relationship between the government and the market to promote a more efficient and healthier growth path of the economy through technological innovation and industrial upgrading.

Therefore, the future of China's economy depends highly on whether it can achieve fruitful technological innovation and industrial upgrading. As a representative of efficient productivity, private enterprises are an important force to support China's sustainable and rapid economic growth, also as the main force of technological innovation.

However, Chinese private enterprises face serious problems. Since the reform and opening up for more than 40 years, although China's commodity market has been open and free, the development of factor markets has lagged behind seriously. National departments and government agencies still play a decisive leading role in resource allocation. This problem is particularly acute over the allocation of key resources such as financial resources and business opportunities. State-owned enterprises (SOEs) with a relatively superior political status are more likely to obtain resources than those private enterprises with higher productivity.

The discriminatory resource allocation system has led to more and more private enterprises begin to attach importance to the strategy of political connections, which have greatly affected the decision-making of enterprises. Private enterprises with political connections can obtain the resources required for production, thus achieve rapid growth more easily. On the other hand, political connections enable private enterprises to obtain financial resources as well as business opportunities more conveniently and quickly, which means that companies are more inclined to exploit the resources brought by political connections. Such convenience induces companies to ignore management and technological innovations, leading to its long-term production efficiency decline.

The influence of political connections on corporate decision-making deteriorates the innovation capability and operational efficiency of enterprises, further restricts the potential long-term growth. It is a major institutional drawback in the process of China's reform and pursuing economic breakthroughs. Via the innovation capability of enterprises, this paper attempts to clarify the impact of political connections on the potential long-term growth of enterprises. In the meantime, it is beneficial to understand the institutional problems existing in current China's economy to a certain extent, also to acquire a better understanding of some informal mechanisms such as 
political connections in the transition economies. The latter provides a different microscopic perspective on the analysis of the long-term growth of the transition economies.

From a theoretical perspective, the widespread political connections have attracted many scholars' attention, and research has achieved numerous results. With the joint efforts of many scholars, the study of political connections has achieved a wealth of research results. However, most of the research focuses on short-term effect such as value and benefits brought by political connections. In addition, most political connection studies focus on the short-term effects without a thorough exploration of the specific mechanism of the influences, resulting in different conclusions based on different samples.

This paper includes all the non-financial private listed companies of Shanghai and Shenzhen stock exchanges, the data structure is unified, the quality is high, and it can provide high-quality data samples for the analysis. It helps us to accurately analyze the specific impact of political relevance on enterprise innovation. The microstructure of data fills in the gap in this field, promoting the research to the endogenous response of enterprises.

The remaining structure of this paper is as follows. The second part is literature review, which mainly introduces the research of political connection and enterprise innovation. The third part is the research method, which includes data source, variable design, model and regression methods. The fourth part is the empirical results and discussion, analyzing the impact of political connections on corporate innovation and the mechanism, taking advantage of the entry level of barrier industries to verify the mechanism. The last part summarizes and proposes policy recommendations.

\section{Literature Review}

In recent years, China's private enterprises have paid more and more attention to establishing political connections, some enterprises have even implemented it as core strategies. The widespread existence of political connections has aroused the academic attention and strong research interest, leading to considerable research. Most of the research focuses on the value and benefits brought by political connections, especially in terms of corporate value, financing convenience, government subsidies, and tax incentives.

The first systematical analysis of the relationship between political connections and corporate values was conducted by Fishman (2001). The rumors of the deterioration of the health status of Indonesian President Suharto from 1995 to 1997 was considered as an event window. Event study was adopted to examine the impact of rumors on the value of politically connected enterprises, which found that Suharto's negative health rumors would lead to a decline in the market value of affiliated companies. Besides, the higher the degree of association, the more the value declines. Scholars such as Johnson and Mitton (2003), Jayachandran (2006), Knight (2006), and Claessens et al. (2008) conducted similar studies on the similar events in the United States, Brazil, and Thailand, all drawing the conclusion that the existence of political connections improves the companies' value. However, Fisman et al. (2006) conducted a study of the sample companies that maintained a political connection with Vice President Cheney in the United States, which found that political connections did not significantly improve corporate value. Bertrand et al. (2007) and Faccio (2006) had similar conclusions on studies in several other countries.

In order to alleviate the disadvantage that the results of the event study are disturbed by small sample problems, Faccio and Parsley (2009) showed new research by expanding the sample size. Based on the accidental deaths of 122 politicians around the world from 1973 to 2004, and subsequent studies on the performance of their listed companies, they found that when the political figures who have political connections with the company suddenly died suddently, both the stock price and the sales growth rate of the enterprise will decline significantly. Research of Dombrovsky $(2010,2011)$ based on panel research by Latvian companies revealed that the existence of political connections can significantly increase the sales of enterprises.

The studies of political connections relating to Chinese companies focus on a similar theoretical perspective. A study of the former Shanghai Municipal Party Committee Secretary Chen Liangyu's "social security case", which was conducted by $\mathrm{Xu}$ and Zhou (2008), finding that the disappearance of political connections would significantly reduce the market value of affiliated companies. Li et al. (2008) showed that the membership of private entrepreneurs would improve the profitability of corporate assets based on the 2002 national private enterprise survey data. Wu et al. (2010) argued that the analysis based on the data of listed companies in China shows political connections increased their corporate value for private enterprises, while the effect was completely opposite for state-owned enterprises. However, Du Xingqiang et al. (2009) did not find that political connections significantly improved the performance of private listed companies, and Deng Jianping and Zeng Yong (2009) suggested that the higher the degree of political relevance, even the worse of the business 
performance.

In the study based on Chinese companies, Bai et al. (2006), Yu Minggui and Pan Hongbo (2008), Luo Danglun and Yan Liming (2008) and Yu Wei et al. (2012) all found that companies with political connections contained financing convenience. Firth et al. (2009) used a survey of corporate loans by private companies in the World Bank (2003) and data from the National Bureau of Statistics, suggesting that political connections are considered to be an important factor in commercial banks' lending activities in addition to commercial interests when making loans.

Moreover, studies by Faccio et al. (2006), Adhikari et al. (2006), and Mobarak and Purbasari (2006) found that political connections guarantee more government subsidies, lower effective tax rates and weaker entry barrier. A similar study on China also pointed out that political connections lead to government subsidies (Yu Minggui et al., 2010) and tax incentives (Wu Wenfeng et al., 2009). The research by Yu Minggui et al. (2010) suggested that the worse the institutional environment of the location of the enterprise, the stronger the effect of subsidies for political connections. However, political research based on China also found that political connections also increase the policy burden of enterprises and make them more vulnerable to government plunder, while they bring benefits to enterprises simultaneously. As studied by Wu et al. (2010), it is found that state-owned enterprises with political connections often have more severe labor over employment. Cheung et al. (2010) showed that local governments would benefit from state-owned enterprises through connected transactions based on a sample of listed companies with state-controlled shareholders.

Political connections promote companies to break through industry barriers. Stigler (1968) defines entry barriers as additional production costs that must be borne by new businesses trying to enter an industry without the burden on the incumbent. Broadman (2000) divides entry barriers into two categories: market barriers and regulatory barriers according to different formation reasons. The former mainly refers to industrial barriers formed by economies of scale, product differentiation and absolute cost (Bain, 1956); the latter is often generated by government-controlled industries .

Chinese private enterprises face severe entry barriers, which is caused by the government's strict control over specific industries. Bain (1956) pointed out that political connections enable private enterprises to break through regulatory barriers and enter traditional regulatory industries, thereby increasing investment returns. Research based on Chinese corporate samples has also reached a similar conclusion. Hu Xuyang (2006) showed that the political connection of entrepreneurs could effectively help enterprises enter the financial industry through the study of the top 100 private enterprises in Zhejiang Province in 2004. Luo Danglun and Liu Xiaolong (2009) found that when some regulated industries are gradually deregulated, enterprises with political connections are more likely to enter these industries compared with unrelated enterprises, and most of these industries are traditional industries such as energy, mining and automobile manufacturing which are monopolised by traditional state-owned corporations.

Schumpeter (1934) mentioned the enormous role of innovation in economic growth in the book Economic Development Theory. Porter (1990) also emphasized the importance of innovation. Along with the continuous decline of China's economic growth rate, both the decision-making and academic circles have been concerns with the sustainability of China's economic growth sources. The development of future China's economy depends highly on whether it can achieve fruitful technological innovation and industrial upgrading. As an important force supporting the sustained, rapid and steady growth of China's economy and the main source for China's technological innovation activities, private enterprises play an important role in improving China's independent innovation capability and promoting China's economic transformation.

Guan and Liu (2005) pointed out that invention patents used as a measure of corporate innovation indicators have two major advantages. Firstly, it is more accurate than other indicators, such as the publication of technical academic articles is more suitable for the commercial use of R\&D activities (Archibugi, 1988), thus it is more representative of business value and economic efficiency. Secondly, patent data relies on prior work, indicating that patent data is the result of R\&D activities (Furman et al., 2002; Liu \& White 2001), and is a transformative outcome based on R\&D investment. Therefore, it is an appropriate compromise approach to use invention patent as a description of enterprise innovation ability, combining pre-investment and post-production.

Pavitt (1988) pointed out that the advantages of invention patents used to describe the innovation ability from two major aspects. Firstly, the invention patent is registered and certified by the official institutions, removing uncertainty, being more intuitive and easier to understand, excluding measurement error and random data collection bias. Secondly, the invention patent is granted by the official institutions, thus the quality of the patent is guaranteed by the uniform auditing standard, which is conducive to the horizontal comparison. 


\section{Research Method}

\subsection{Data Source}

This paper selects the non-financial private listed companies that are continuously listed in the Shanghai and Shenzhen stock exchanges from 1998 to 2015 as the original sample and builds a micro database including financial data, innovation data, and executive data. The definition of private listed companies in this paper is based on whether the actual controller is a natural person. To be more precise, private listed companies refer to listed companies that are ultimately controlled by individuals or families.

One of the important reasons for choosing private listed companies as research samples is that listed companies meet with multiple requirements for information disclosure, which facilitates accurate access to politically relevant information of corporate executives through open channels. The sample time of this paper was selected for consideration of the uniformity of accounting standards and the accuracy of data. The financial data corresponding to the invention patents had a more standardized and unified standard after 1998. Since invention patents require a review period of two or three years, the sample data is scheduled to expire until the end of 2015 in order to avoid the impact of the time required by the National Patent Office's review and release process.

Unlike the early political connections research, the sample in this paper does not include backdoor listing companies. The political connections of such companies may have been established before privatization (Yu Minggui \& Pan Hongbo, 2008). The composition of its executives is more complicated, and high-level personnel arrangements are often the result of compromises in the process of corporate control transfer (Deng Jianping \& Zeng Yong, 2009). In order to protect the analysis of this article from the above complex factors, we limit the sample to the private listed enterprise.

The data involved corporate financial governance data, innovation data, executive political relevance information, and human capital information. Financial governance data is taken from the CSMAR database. Innovative data comes from the national patent inquiry system. Executive information is collected manually. With the manual search of Sina and Phoenix, information on the general managers and chairman (including the term of appointment, date of birth, gender, education level, and political related information, etc.) is collected, and Google is used to complete such information as much as possible. By convention, we eliminate companies that are specially treated and perform winsorize on continuous variables at $1 \%$ and $99 \%$ level to avoid the impact of extreme values.

\subsection{Variable Design}

The core variables are mainly political connections, innovation efficiency, and corporate characteristics. We use the political identity of corporate executives as a proxy variable. Literature usually refers to the general manager as the company's executives. Under the company law in China, the chairman is the legal representative of the company and has an important responsibility for business operations. This article follows the practices of $\mathrm{Yu}$ Minggui and Pan Hongbo (2008), Wu et al. (2012), and considers the political status of the chairman and the general manager. With regard to the definition of political identity, scholars mentioned before consider the government and military experience of executives. Moreover, the experience of the NPC and the CPPCC is also very important (Bai et al., 2006; Li et al., 2006). Being a deputy to the National People's Congress or a member of the Chinese People's Political Consultative Conference means a more direct and effective influence on the formulation and implementation of policies (Chen et al., 2008). Therefore, the political relationship POL referred in this study includes both the government (including the permanent establishment of the CPPCC) and the military experience, as well as current or former NPC deputies and CPPCC members. As long as the chairman or general manager has one of the above political experiences, we define the company as a politically connected company, $P O L$ takes 1 , otherwise, it takes 0 .

The number of patents successfully applied for and reviewed by listed companies during the reporting period is applied as a proxy variable for enterprise innovation. From China National Patent Inquiry System, patents are divided into for categories, that is invention licenses, invention applications, utility models and designs. The utility model refers to a new technical solution of practical usage for the shape, structure or combination of the products; the design refers to the new design which is aesthetics and having industrial application for the shape, pattern, color or combination of the products; the invention application refers to the potential invention patent that has been applied but has not been confirmed by the review. After the approval, it will exist as the invention authorization; the invention authorization refers to the new technical solutions to product, method or other improvement. In general, inventions have a higher technical value, while utility models and designs have lower technical value. We obtain the number in turn and calculate the sum of invention applications and invention licenses as the overall patents' indicators. Due to the diversification of some listed private companies, the costs 
and benefits of R\&D and innovation activities of listed companies and their subsidiaries are often borne by different entities, and the R\&D cost input data in the listed company's annual report is highly concentrated. Therefore, in the process of empirical analysis, we use the sum of the patents of parent company itself and all its subsidiary companies to calculate the number of patents used for subsequent analysis.

In addition to the above-mentioned indicators, with reference to common practices, we use the company size, Size, measured by the logarithmic total assets; enterprise age, Age, measured by the logarithmic the year established; long-term debt ratio, Lev, measured by long-term liabilities divided by total assets; ROE; asset structure, $P P E$, measured by fixed assets divided by total assets; $\mathrm{R} \& \mathrm{D}$ intensity, $R D s$, measured by management expenses divided by total sales revenue; equity concentration, $H 10$, measured by the square of the shareholding ratio of the top ten shareholders; whether the controller is also the chairman or general manager, Ucpd, which takes 1 when the listed company controller is the chairman or general manager, otherwise 0 ; whether the chairman and the general manager are the same person, Presmn, which is 1 when the chairman and general manager of the listed company are the same person, otherwise 0. Executive human capital information consists of executive gender, age, the experience of industry and commerce, party membership, work experience, and education. Among them, if the senior management has the experience of the Federation of Industry and Commerce, then the Federation of Industry and Commerce will experience takes 1; if the senior executive is a member of the Communist Party, the party membership takes 1; if the senior executive has experience in accounting, finance, law, banking or securities, then profession takes 1 ; otherwise takes 0 , the final executive work experience indicators are summed up from the above five aspects. The degree of education of executives is based on the disclosure of executive resumes, which distinguishes junior high school students, high school secondary schools, junior colleges, undergraduates, masters and doctors, and assigns them accordingly. For the purpose of data consistency and simplicity, the average value of the human capital information of the general manager and the chairman of the board is used in the econometric analysis.

Due to the large revision of the accounting standards around 2007, the $R \& D$ expenditures of listed companies before 2007 were not included in each database. At the beginning of the research, we manually calculated the $R \& D$ expenditures through the annual reports of listed companies. But if $R \& D$ investment is used to calculate R\&D intensity, about $30 \%$ of the samples can be used. In order to use the sample information fully, under the condition that there is a high correlation coefficient between $\mathrm{R} \& \mathrm{D}$ expenditure and management cost, this paper follows the general practice and uses the management fee as the proxy variable of $R \& D$ expenditure to calculate the R\&D intensity. Although this method contains limitations, it can greatly increase the number of available samples and improve the accuracy of estimation.

Considering that political connections weaken the entry barriers of some industries to a certain extent, thus enables excessive profits available, and damage the innovation incentives of the enterprises. We especially examine whether political connections can help enterprises enter high-barrier industries. This article measures the degree of entry into the barrier industry by Barr (100\% of the unit) of sales of the barrier industry. With reference to Luo Danglun and Liu Xiaolong (2009), we define hydropower, coal, oil, steel, non-ferrous metals, aerospace, salt, tobacco, railway, aviation, telecommunications, postal and financial industries as high barrier industries.

Table 1. Statistical description of major variables

\begin{tabular}{lccccccc}
\hline \multicolumn{7}{c}{ Full sample } & \multicolumn{3}{c}{ Group mean } \\
\hline variables & Mean & $\begin{array}{c}\text { Standard } \\
\text { deviation }\end{array}$ & Minimum & Maximum & $\begin{array}{c}\text { (1) Politically } \\
\text { connected }\end{array}$ & $\begin{array}{c}(2) \text { Non-political } \\
\text { connected }\end{array}$ & $\begin{array}{c}(1)-(2) \\
\text { Difference }\end{array}$ \\
\hline POL & 0.466 & 0.499 & 0 & 1 & & & \\
innovapp & 7.135 & 112.4 & 0 & 4148 & 2.511 & 11.16 & $-8.651^{* *}$ \\
innov & 8.882 & 126.0 & 0 & 3597 & 3.471 & 13.59 & $-10.12^{* *}$ \\
innovuse & 7.213 & 27.69 & 0 & 583 & 6.739 & 7.625 & -0.8867 \\
innovdesign & 3.018 & 17.08 & 0 & 571 & 2.987 & 3.046 & -0.0589 \\
innovsum & 16.02 & 219.1 & 0 & 5815 & 5.982 & 24.76 & $-18.77^{* *}$ \\
size & 21.06 & 0.988 & 16.51 & 25.38 & 21.16 & 20.98 & $0.1814^{* * *}$ \\
fmage & 11.70 & 4.442 & 0 & 30 & 11.18 & 12.14 & $-0.9641^{* * *}$ \\
lev & 0.470 & 0.945 & 0.00708 & 27.92 & 0.4236 & 0.5109 & $-0.0872^{* *}$ \\
ROE & 0.0734 & 0.821 & -23.96 & 26.06 & 0.1001 & 0.0502 & 0.0499 \\
PPE & 0.383 & 0.189 & 0.00113 & 0.981 & 0.3975 & 0.3710 & $0.0265^{* * *}$ \\
RDs & 0.929 & 39.97 & -0.00714 & 2115 & 1.720 & 0.2399 & 1.480 \\
\hline
\end{tabular}




\begin{tabular}{lccccccc}
\hline Ucpd & 0.748 & 0.434 & 0 & 1 & 0.8161 & 0.6920 & $0.1241^{* * *}$ \\
Presmn & 0.258 & 0.438 & 0 & 1 & 0.1910 & 0.3162 & $-0.1253^{* * *}$ \\
gender & 0.949 & 0.175 & 0 & 1 & 0.9425 & 0.9548 & $-0.0124^{*}$ \\
age & 46.26 & 6.163 & 29.5 & 66.5 & 46.89 & 45.54 & $1.353^{* * *}$ \\
business & 0.1124 & 0.2645 & 0 & 1 & 0.1974 & 0.0255 & $0.1718^{* * *}$ \\
party & 0.4191 & 0.4282 & 0 & 1 & 0.5150 & 0.3201 & $0.1950^{* * *}$ \\
edu & 3.198 & 0.838 & 0 & 5 & 3.173 & 3.219 & -0.0463 \\
exp & 0.111 & 0.316 & 0 & 3 & 0.1207 & 0.1017 & 0.0191 \\
manaparty & 0.364 & 0.421 & 0 & 1 & 0.4513 & 0.2884 & $0.1628^{* * *}$ \\
linnov & 0.661 & 1.031 & 0 & 8.188 & 0.6425 & 0.6773 & -0.0348 \\
linnovsum & 1.434 & 1.551 & 0 & 8.765 & 1.382 & 1.479 & $-0.0970^{* * *}$ \\
barr & 0.730 & 7.823 & 0 & 179.1 & 0.3769 & 1.037 & $-0.6599 * *$ \\
\hline
\end{tabular}

Note. $* * *, * *, *$ indicates significant at the $1 \%, 5 \%$, and $10 \%$ levels; the table below is the same.

Table 1 shows a statistical description of the main variables, displaying the mean of each variable grouped by political association. The mean value of the political association POL is approximately 0.466. The data shows that the Invention application (Innovapp), invention authorization (Innov) and patent sum (Innovsum) of politically affiliated companies are significantly lower than those of non-political affiliates.

\subsection{Basic Model: Influence of Political Connections on Innovation}

This paper uses the following empirical model to test the impact of political connections on business innovation:

$$
\text { Innovation }_{i t}=\alpha P O L_{i t}+\beta X_{i t}+\text { Year }+u_{i t}+\varepsilon_{i t}
$$

Innovation in equation (1) represents the ability of an enterprise to innovate, measured by the specific number of patents of listed companies in the reporting period. $P O L$ stands for politically related variables. $X$ are the control variables. Year is the year dummy variable used to control the year effect, $u_{t}$ represents the individual effect of the firm and $\varepsilon_{i t}$ indicates the specificity error. Symbol and significance of $\alpha$ are our focus.

Existing research on political association mostly adopts the method of mixed regression. The estimation result may have endogenous bias due to the missing variable and the two-way causal problem. To be worse, some unobservable factors may have an impact on both political connections and corporate innovation capabilities. If those two effects work oppositely, then political connections and corporate innovation capabilities will show opposite trends. A large part of the results of the general OLS estimates should be attributed to such factors. Regardless of the impact of political linkages on enterprise innovation, OLS estimates are inaccurate.

To alleviate the influence of endogenous problems, we use the fixed effect method (FE). FE effectively controls non-time-varying factors in non-observation effects and alleviates the influence of endogenous problems to a certain extent. Since the dependent variable is a series of non-negative integers starting from 0 , and the variance of various invention patents is greater than mean, we use the FE model of the negative binomial panel. Tests show that the random effects model is not suitable here. We calculate the correlation coefficient between the main continuous variables, and results suggest that no significant multicollinearity problems exist.

\subsection{Development Time and Lag Period Selection}

In China National Patent Inquiry System, the invention patent has four sub-categories of utility model, design, invention application, and invention authorization. Utility models and designs have shorter development times, while invention patents have longer development time. If the total number of invention patents is used as the representative of the innovation ability, the obtained results are easily affected by the proportion of the invention patents of each company, which induce estimation errors. Therefore, independent analysis of various types of patents is required, which means determining the specific time required for the development of various types of invention patents.

We detail the development time of the listed company's R\&D projects disclosed by the CSMAR database. The specific strategy is to compare the patents applied by companies and their subsidiaries in the patent system through the disclosure of the R\&D expenditures. By matching the patent name with the R\&D expenditure item, the difference between the start time of the $R \& D$ expenditure item and the corresponding application time of the corresponding patent application project is the time required for development. Considering that the same R \& D project will continue for multiple periods, it will respond to multiple patent applications, the development time of the application project that appears earlier will be calculated according to the time interval between the project and the earliest application project. All subsequent application items are determined in the similar method. After 
eliminating the uncertain samples, the development time distribution of the three categories of patents is shown as follows:

Table 2. Time distribution of various types of invention and patents

\begin{tabular}{lcccc}
\hline Development time & Within 1 year & 1 year & 2 years & 3 years and more \\
\hline Utility model & $76.7 \%$ & $23.3 \%$ & 0 & 0 \\
Design & $89.3 \%$ & $10.7 \%$ & 0 & 0 \\
Invention authorization (invention application) & 0 & $26.9 \%$ & $65.4 \%$ & $7.7 \%$ \\
\hline
\end{tabular}

As a result, the average development time for utility models and designs is 0 year (ie, completed within one year), and the average development time for invention authorization (invention application) is 2 years. The purpose of confirming the development time is to determine the specific lag order of the R\&D intensity variables. From the results, the current value of R\&D intensity can be directly used in the regression of utility models and designs, while the invention authorization may require regression using the lagging $R \& D$ intensity.

However, it shows that a significant correlation exists between the current value of R\&D expenditure and the first-order lag value as well as the second-order lag value through correlation analysis. The correlation coefficients are respectively 0.7751 and 0.7123 , and the correlation coefficients of the first-order lag value and the second-order lag value is up to 0.8783. Considering that the current $R \& D$ investment of enterprises has the greatest impact on R\&D output, in order to reduce the multi-collinearity problem existing in regression analysis and improve the estimation efficiency, the current $R \& D$ intensity is also used in the analysis of the invention authorization and invention application.

\section{Results and Discussion}

\subsection{Basic Regression: Influence of Political Connections on Innovation}

To explore the impact of political connections on business innovation, we run the regression which we have set up in the research method part. Results of the estimation between the political connections $(P O L)$ and the invention authorization (Innov) are listed in Table 3. After controlling the enterprise's characteristic variables, regression (1) to (4) all include the business executives' experience and party membership variables. After controlling whether the actual controller is the general manager or chairman (Ucpd), regression (1) and (2) are comparisons, their difference is that only one model contains variable Presmn (whether the general manager and the chairman are the same person). Similarly, regression (3) and (4) are comparisons of variable Ucpd. These four results show that political connections deteriorate corporate invention authorizations. Each result is significant at a 5\% confidence level, the signs and significantness of control variables coefficients are consistent with economic intuition. This shows that the damage of political connection to the inventive authorization is more obvious.

Table 3. FE regression between political connections and corporate innovation (invention authorization)

\begin{tabular}{|c|c|c|c|c|}
\hline & \multicolumn{4}{|c|}{ Innov(invention authorization) } \\
\hline & $(\mathbf{1})$ & $(2)$ & (3) & (4) \\
\hline \multirow[t]{2}{*}{$P O L$} & $-0.300^{* *}$ & $-0.299^{* *}$ & $-0.265^{* *}$ & $-0.264^{* *}$ \\
\hline & $(0.129)$ & $(0.129)$ & $(0.123)$ & $(0.123)$ \\
\hline \multirow[t]{2}{*}{ size } & $0.475^{* * *}$ & $0.478^{* * *}$ & $0.484^{* * *}$ & $0.485^{* * *}$ \\
\hline & $(0.0762)$ & $(0.0759)$ & $(0.0744)$ & $(0.0742)$ \\
\hline \multirow[t]{2}{*}{ fmage } & -0.0226 & -0.0221 & -0.0139 & -0.0139 \\
\hline & $(0.0227)$ & $(0.0227)$ & $(0.0224)$ & $(0.0224)$ \\
\hline \multirow[t]{2}{*}{ lev } & -0.0830 & -0.0996 & -0.180 & -0.181 \\
\hline & $(0.303)$ & $(0.300)$ & $(0.295)$ & $(0.294)$ \\
\hline \multirow[t]{2}{*}{$R O E$} & $1.135^{* * *}$ & $1.143^{* * *}$ & $1.116^{* * *}$ & $1.117^{* * *}$ \\
\hline & $(0.426)$ & $(0.426)$ & $(0.420)$ & $(0.419)$ \\
\hline \multirow[t]{2}{*}{$P P E$} & $0.591^{*}$ & $0.604^{*}$ & $0.643^{*}$ & $0.644^{*}$ \\
\hline & $(0.346)$ & $(0.345)$ & $(0.340)$ & $(0.339)$ \\
\hline \multirow[t]{2}{*}{$\mathrm{H1O}$} & 0.0197 & 0.0239 & -0.0750 & -0.0741 \\
\hline & $(0.671)$ & $(0.671)$ & $(0.654)$ & $(0.654)$ \\
\hline \multirow[t]{2}{*}{$R D s$} & 1.307 & 1.300 & 1.077 & 1.077 \\
\hline & $(0.801)$ & $(0.801)$ & $(0.762)$ & $(0.762)$ \\
\hline
\end{tabular}




\begin{tabular}{|c|c|c|c|c|}
\hline \multirow[t]{2}{*}{ business } & $-0.443^{*}$ & $-0.454^{*}$ & -0.333 & -0.335 \\
\hline & $(0.245)$ & $(0.243)$ & $(0.239)$ & $(0.238)$ \\
\hline \multirow[t]{2}{*}{ party } & -0.127 & -0.139 & -0.118 & -0.119 \\
\hline & $(0.158)$ & $(0.156)$ & $(0.154)$ & $(0.152)$ \\
\hline \multirow[t]{2}{*}{ Ucpd } & $0.420^{* * *}$ & $0.414^{* * *}$ & & \\
\hline & $(0.133)$ & $(0.133)$ & & \\
\hline \multirow[t]{2}{*}{ Presmn } & -0.0485 & & -0.00628 & \\
\hline & $(0.111)$ & & $(0.109)$ & \\
\hline \multirow[t]{2}{*}{ _cons } & $-11.61^{* * *}$ & $-11.66^{* * *}$ & -24.80 & -27.35 \\
\hline & (1.618) & (1.613) & (471.4) & (1678.2) \\
\hline$N$ & 1514 & 1514 & 1687 & 1687 \\
\hline
\end{tabular}

Note. (1) The value in () is a stable standard error of each explanatory variable; similar below.

(2) For reasons of space, the year effect is omitted from the results; similar below.

The estimates of political connection on other types of invention patents are listed in Table 4. On the basis of controlling the characteristic variables of the enterprise, regressions (1) to (4) control the business association experience and party membership of corporate executives. After controlling whether the actual controller is the general manager or chairman $(U c p d)$, regression (1) and (2) are comparisons, their difference is that only one model contains variable Presmn (whether the general manager and the chairman are the same person). In contrast, regression (3) and (4) are comparisons of variable Ucpd. Results show that political connection only has a significant detrimental effect on the total patent, no significant detrimental effect appeared on the invention applications, utility models and designs.

Table 4. FE regression between the political connections and corporate innovation (other innovation)

\begin{tabular}{|c|c|c|c|c|}
\hline & \multicolumn{4}{|c|}{ Innovapp(invention application) } \\
\hline & (1) & (2) & (3) & (4) \\
\hline \multirow[t]{2}{*}{$P O L$} & -0.103 & -0.0954 & -0.0998 & -0.0922 \\
\hline & $(0.146)$ & $(0.146)$ & $(0.139)$ & $(0.139)$ \\
\hline \multirow[t]{3}{*}{$N$} & 1429 & 1429 & 1612 & 1612 \\
\hline & \multicolumn{4}{|c|}{ Innovuse(utility model) } \\
\hline & (1) & (2) & (3) & (4) \\
\hline \multirow[t]{2}{*}{$P O L$} & -0.151 & -0.145 & -0.0655 & -0.0582 \\
\hline & $(0.125)$ & $(0.125)$ & $(0.119)$ & $(0.118)$ \\
\hline \multirow[t]{3}{*}{$N$} & 1470 & 1470 & 1663 & 1663 \\
\hline & \multicolumn{4}{|c|}{ Innovdesign(design) } \\
\hline & (1) & (2) & (3) & (4) \\
\hline \multirow[t]{2}{*}{$P O L$} & 0.216 & 0.213 & 0.157 & 0.155 \\
\hline & $(0.173)$ & $(0.173)$ & $(0.164)$ & $(0.164)$ \\
\hline \multirow[t]{3}{*}{$N$} & 979 & 979 & 1149 & 1149 \\
\hline & \multicolumn{4}{|c|}{ Innovsum(total patent) } \\
\hline & (1) & $(2)$ & (3) & (4) \\
\hline \multirow[t]{2}{*}{$P O L$} & $-0.223^{* *}$ & $-0.213^{* *}$ & $-0.168^{*}$ & $-0.156^{*}$ \\
\hline & $(0.0969)$ & $(0.0971)$ & $(0.0913)$ & $(0.0914)$ \\
\hline$N$ & 1709 & 1709 & 1921 & 1921 \\
\hline
\end{tabular}

The above results show that political connection does deteriorate the innovation ability of enterprises, with invention authorization most obvious. This is also in line with the basic intuition that the invention authorization is the most technical and best representative of the companys' abilities of innovation. As the largest component of the total patent, the relationship between the invention authorization and the political connection makes the patent sum also affected by the damage effect of the political connection, to a certain extent, it is also economically significant. However, further analysis is necessary for the robustness test for this effect, relevant impact mechanisms also require more in-depth analysis.

\subsection{Analysis of the Mechanism}

The regression analysis of the above part has verified the deterioration effect of political connection on the sum 
of invention authorization and patent, thus basically revealed the deterioration effect of political connection on enterprise innovation.

Political connections weaken entry barrier, thus enterprises can rely on non-market forces to obtain excess profits and weaken the innovation incentives of enterprises. To clarify the specific influence mechanism of political connection on enterprise innovation, we will analyze the changes in the degree of entry barriers in the industry after obtaining political connections. On this basis, we further analyze the impact of this change on corporate innovation. For the sake of simplicity and accuracy, the enterprise innovation ability is expressed only with the invention authorization indicator.

Table 5 reports the results of the fixed effects of the entry level of the barrier industry on political connections. After controlling various enterprise characteristic variables and corporate executive characteristic variables, the FE regression results in Table 5 show that political connection plays a significant role in promoting the company's entry degree of barrier industry. The coefficient of the political correlation $(P O L)$ of the core variables is relatively stable in each regression result, while the significance level of each coefficient is low. For the sake of higher stability of the political correlation coefficient, the regression (3) is used to calculate the fitted value of Barr (barrier industry entry degree), and the subsequent analysis is performed accordingly.

Table 5. FE regression between Barr and political connections

\begin{tabular}{|c|c|c|c|c|}
\hline & \multicolumn{4}{|c|}{ Barr (barrier industry entry degree) } \\
\hline & (1) & (2) & (3) & (4) \\
\hline \multirow[t]{2}{*}{$P O L$} & $3.787^{* * *}$ & $3.805^{* * *}$ & $3.638^{* * *}$ & $3.966^{* * *}$ \\
\hline & $(1.210)$ & $(1.184)$ & $(1.188)$ & $(1.205)$ \\
\hline \multirow[t]{2}{*}{ size } & $-1.413^{*}$ & $-1.406^{*}$ & $-1.402^{*}$ & $-1.417^{*}$ \\
\hline & $(0.746)$ & $(0.743)$ & $(0.743)$ & $(0.746)$ \\
\hline \multirow[t]{2}{*}{ lev } & 2.694 & 2.929 & 2.770 & 2.844 \\
\hline & $(2.524)$ & $(2.517)$ & $(2.517)$ & $(2.524)$ \\
\hline \multirow[t]{2}{*}{$R O E$} & -0.302 & -0.431 & -0.290 & -0.440 \\
\hline & $(2.640)$ & $(2.635)$ & $(2.635)$ & $(2.640)$ \\
\hline \multirow[t]{2}{*}{$P P E$} & 0.175 & -0.187 & 0.0752 & -0.0702 \\
\hline & $(2.801)$ & $(2.787)$ & $(2.790)$ & $(2.798)$ \\
\hline \multirow[t]{2}{*}{$H 10$} & 8.462 & 8.429 & 8.586 & 8.293 \\
\hline & $(7.022)$ & $(7.010)$ & $(7.007)$ & $(7.025)$ \\
\hline \multirow[t]{2}{*}{ fmage } & 0.196 & 0.192 & 0.198 & 0.190 \\
\hline & $(0.249)$ & $(0.248)$ & $(0.248)$ & $(0.249)$ \\
\hline \multirow[t]{2}{*}{ Ucpd } & $2.751^{* *}$ & $2.724^{* *}$ & $2.817^{* *}$ & $2.654^{* *}$ \\
\hline & (1.173) & (1.167) & (1.168) & (1.172) \\
\hline \multirow[t]{2}{*}{ business } & 1.945 & & & 2.148 \\
\hline & $(2.922)$ & & & $(2.921)$ \\
\hline \multirow[t]{2}{*}{ party } & 2.366 & $2.807^{*}$ & 2.381 & 2.783 \\
\hline & (1.710) & (1.682) & $(1.701)$ & (1.691) \\
\hline \multirow[t]{2}{*}{ Presmn } & 1.636 & & $1.666^{*}$ & \\
\hline & (1.015) & & (1.012) & \\
\hline \multirow[t]{2}{*}{ _cons } & $30.17^{* *}$ & $30.61^{* *}$ & $29.97^{* *}$ & $30.78^{* *}$ \\
\hline & (15.15) & (15.09) & (15.08) & (15.16) \\
\hline$R^{2}$ & 0.025 & 0.023 & 0.024 & 0.023 \\
\hline$N$ & 2157 & 2161 & 2161 & 2157 \\
\hline
\end{tabular}

The FE estimates for the Barr fit values and other control variables for enterprise invention authorization are listed in Table 6. The coefficients of each variable accord with the economic intuition. The stability of the coefficient after increasing or decreasing the variable and the significance of each control variable are exceptional. The results show that the increase in the entry level of the barrier industry will indeed damage the company's invention authorization. Although the level of significance has declined, political connections still undermine invention authorizations. However, the coefficient of political correlation and the significant level of the coefficient of entry into the barrier industry cannot simultaneously maintain a relatively significant level. The decline in the level of significance of the coefficient may be due to the correlation between political connections and barrier entry degree. Therefore, the regression conclusion is accurate to some extent. 
In conclusion, political connections will increase the entry level of the barrier industry, ultimately deteriorate company's inventions authorization, which means that the path relating to industry entry barrier degree does exist.

Table 6. FE regression between invention authorization, political connections and Barr

\begin{tabular}{|c|c|c|c|c|}
\hline & \multicolumn{4}{|c|}{ Innov (invention authorization) } \\
\hline & (1) & (2) & (3) & (4) \\
\hline \multirow[t]{2}{*}{$P O L$} & -0.406 & -0.376 & $-0.455^{* *}$ & $-0.505^{*}$ \\
\hline & $(0.275)$ & $(0.174)$ & $(0.181)$ & $(0.270)$ \\
\hline \multirow[t]{2}{*}{ barr_hat } & -0.0291 & $-0.0867^{* *}$ & -0.0413 & -0.0426 \\
\hline & $(0.0664)$ & $(0.0359)$ & $(0.0429)$ & $(0.0663)$ \\
\hline \multirow[t]{2}{*}{ size } & $0.434^{* * *}$ & $0.602^{* * *}$ & $0.415^{* * *}$ & $0.408^{* * *}$ \\
\hline & $(0.125)$ & $(0.0941)$ & $(0.0962)$ & $(0.124)$ \\
\hline \multirow[t]{2}{*}{ fmage } & -0.0168 & -0.0384 & -0.0146 & -0.00697 \\
\hline & $(0.0257)$ & $(0.0235)$ & $(0.0240)$ & $(0.0252)$ \\
\hline \multirow[t]{2}{*}{ lev } & -0.00245 & -0.431 & 0.0414 & 0.0666 \\
\hline & $(0.373)$ & $(0.312)$ & $(0.325)$ & $(0.372)$ \\
\hline \multirow[t]{2}{*}{$R O E$} & $1.127^{* * *}$ & $1.189^{* * *}$ & $1.120^{* * *}$ & $1.152^{* * *}$ \\
\hline & $(0.427)$ & $(0.427)$ & $(0.426)$ & $(0.428)$ \\
\hline \multirow[t]{2}{*}{$P P E$} & $0.593^{*}$ & $0.644^{*}$ & $0.582^{*}$ & $0.592^{*}$ \\
\hline & $(0.345)$ & $(0.344)$ & $(0.342)$ & $(0.346)$ \\
\hline \multirow[t]{2}{*}{ H1O } & 0.269 & -0.707 & 0.376 & 0.259 \\
\hline & $(0.875)$ & $(0.732)$ & $(0.755)$ & $(0.877)$ \\
\hline \multirow[t]{2}{*}{$R D s$} & 1.307 & 1.206 & $1.317^{*}$ & 1.228 \\
\hline & $(0.801)$ & $(0.798)$ & $(0.800)$ & $(0.802)$ \\
\hline \multirow[t]{2}{*}{ business } & $-0.443^{*}$ & $-0.454^{*}$ & $-0.435^{*}$ & \\
\hline & $(0.245)$ & $(0.243)$ & $(0.243)$ & \\
\hline \multirow[t]{2}{*}{ party } & -0.0580 & $-0.384^{* *}$ & & 0.00243 \\
\hline & $(0.242)$ & $(0.184)$ & & $(0.239)$ \\
\hline \multirow[t]{2}{*}{ Ucpd } & $0.502^{* *}$ & & $0.539^{* * *}$ & $0.517^{* *}$ \\
\hline & $(0.239)$ & & $(0.183)$ & $(0.240)$ \\
\hline \multirow[t]{2}{*}{ _cons } & $-10.74^{* * *}$ & $-14.17^{* * *}$ & $-10.34^{* * *}$ & $-10.24^{* * *}$ \\
\hline & $(2.654)$ & $(2.059)$ & $(2.075)$ & (2.644) \\
\hline$N$ & 1514 & 1514 & 1514 & 1516 \\
\hline
\end{tabular}

\section{Conclusions}

It is widely recognized that innovation plays a core driving role in economic growth, which shown by numerous studies that innovation plays an important role in improving the productivity of enterprises, especially in the long-term efficiency. This paper studies the impact of political connections on corporate innovation based on the sample of private listed companies in China. The results show that political-affiliated enterprises are easier to enter the industries with high entry barrier, which undermines the incentives to implement innovation activities simultaneously. The existing research focuses on corporate value, corporate income and corporate performance, with no consensus reached. The findings of this paper make the debate more reasonable, meaning that even if political connections improve companies performance in the short term, they will ultimately hurt the productivity of the company in the long run.

As the main force to promote technological innovation and support economic growth, private enterprises have important significance for the long-term development of China's economy. Unfortunately, some high-quality enterprises are inclined to establish political connections, and then embark on the path of continuous decline in production efficiency. As long as private enterprises are not discriminated for their ownership, the development strategy will no longer rely on political connections. Therefore, in order to fundamentally solve the problem that political connections deteriorate the innovation capability and potential long-term growth of enterprises, it is necessary to reform the existing factor distribution mechanism as soon as possible.

\section{References}

Adhikari, A., Derashid, C., \& Zhang, H. (2006). Public policy, political connections, and effective tax rates: 
Longitudinal evidence from malaysia. Journal of Accounting and Public Policy, 25(5), 0-595. https://doi.org/10.1016/j.jaccpubpol.2006.07.001

Archibugi, D., \& Pianta, M. (1996). Measuring technological change through patents and innovation surveys. Technovation, 16(9), 451-468. https://doi.org/10.1016/0166-4972(96)00031-4

Cheung, Y. L., Rau, P. R., \& Stouraitis, A. (2010). Helping hand or grabbing hand? Central vs. local government shareholders in Chinese listed firms. Review of Finance, 14(4), 669-694. https://doi.org/10.1093/rof/rfp024

Claessens, S., Feijen, E., \& Laeven, L. (2008). Political connections and preferential access to finance: The role of campaign contributions. Journal of Financial Economics, 88(3), 554-580. https://doi.org/10.1016/j.jfineco.2006.11.003

Dombrovsky, V. (2011). Do political connections matter? Firm-level evidence from Latvia. SSRN Electronic Journal. https://doi.org/10.2139/ssrn.1168702

Du X., Guo J., \& Lei Y. (2009). Political contact and private listed company performance: In "government intervention" or "relationship"? Financial Research, 11, 158-173.

Faccio, M. (2006). Politically connected firms. American Economic Review, 96(1), 369-386. https://doi.org/10.2139/ssrn.444960

Faccio, M., Masulis, R. W., \& Mcconnell, J. J. (2006). Political connections and corporate bailouts. The Journal of Finance, 61(6), 2597-2635. https://doi.org/10.1111/j.1540-6261.2006.01000.x

Fisman, \& Raymond. (2001). Estimating the value of political connections. American Economic Review, 91(4), 1095-1102. https://doi.org/10.1257/aer.91.4.1095

Fisman, D., Fisman, R., Galef, J., \& Khurana, R. (2006). Estimating the Value of Connections to Vice-President Cheney. SSRN Electronic Journal.

Furman, J. L., Porter, M. E., \& Stern, S. (2000). The determinants of national innovative capacity. Research Policy, 31(6), 899-933. https://doi.org 10.1016/S0048-7333(01)00152-4

Guan, J., \& Liu, S. (2005). Comparing regional innovative capacities of pr china based on data analysis of the national patents. International Journal of Technology Management, 32(3/4), 225. https://doi.org/10.1504/ijtm.2005.007331

Heflebower, R. B. (1957). Barriers to new competition. Yale Law Journal, 21(4), 488. https://doi.org/10.2307/794056

Hu, X., \& Shi, J. (2006). Political Resources of Private Enterprises and Diversified Investment of Private Enterprises---Taking the Top 500 Private Enterprises in China as an Example. China Industrial Economy, 5, 107-113.

Johnson, S., \& Mitton T. (2003). Cronyism and Capital Controls: Evidence from Malaysia. Journal of Financial Economics, 67(2), 351-382. https://doi.org/10.1016/S0304-405X(02)00255-6

Li, H., Meng, L., Wang, Q., \& Zhou, L. A. (2008). Political connections, financing and firm performance: Evidence from Chinese private firms. Journal of Development Economics, 87(2), 0-299. https://doi.org/10.1016/j.jdeveco.2007.03.001

Liu, X., White, S., Baark, E., Mowery, D., \& Wu, G. (2001). Comparing innovation systems: A framework and application to China's transitional context. Research Policy, 30(7), 1091-1114. https://doi.org/10.1016/S0048-7333(00)00132-3

Luo, D., \& Liu, X. (2009). Political Relations, Entry Barriers and Corporate Performance: Empirical Evidence from Chinese Private Listed Companies. Management World, 5, 97-106.

Mobarak, A. M., \& Purbasari, D. P. (2006). Corrupt Protection for Sale to Firms: Evidence from Indonesia. SSRN Electronic Journal.

Pavitt, K. (1988). Uses and abuses of patent statistics. Handbook of Quantitative Studies of Science and Technology, 509-536. https://doi.org/10.1016/B978-0-444-70537-2.50021-0

Schoar, A. (2002). Effects of corporate diversification on productivity. The Journal of Finance, 57(6), 25. https://doi.org/10.1111/1540-6261.00500

Wu, W., Wu, C., \& Rui, O. M. (2012). Ownership and the value of political connections: Evidence from China. European Financial Management, 18(4). https://doi.org/10.1111/j.1468-036X.2010.00547.x 
Wu, W., Wu, C., \& Yan, M. (2009). Government Background and Tax Preference of Executives of Chinese Listed Companies. Management World, 3, 134-142.

Yu, M., \& Pan, H. (2008). Political Relations, Institutional Environment and Bank Loans of Private Enterprises. Management World, 8, 9-21.

Yu, W., Wang, Y., \& Jin, X. (2012). Political Correlation and Financing Constraints: Information Effect and Resource Effect. Economic Research, 9, 125-139.

\section{Copyrights}

Copyright for this article is retained by the author(s), with first publication rights granted to the journal.

This is an open-access article distributed under the terms and conditions of the Creative Commons Attribution license (http://creativecommons.org/licenses/by/4.0/). 